ORIGINAL ARTICLE

\title{
The Effects of Alkaline Ionized Water Administration to the Total Cholesterol Levels in Patients with Type 2 Diabetes Mellitus Accompanied by Dyslipidemia
}

\author{
ANDRI RAMADHAN ${ }^{1}$, SATRIO ADI WICAKSONO ${ }^{1}$, TAUFIK EKO NUGROHO ${ }^{1}$, SULISTIYATI BAYU UTAMI ${ }^{2}$ \\ ${ }^{1}$ Department of Anesthesiology and Intensive Therapy. Faculty of Medicine, Diponegoro University. Semarang \\ ${ }^{2}$ Department of Cardiology and Vascular Medicine. Faculty of Medicine, Diponegoro University. Semarang \\ J. Prof. H. Soedarto, SH., Tembalang, Semarang, Central Jawa, Indonesia 50275. Telephone/Fax . +62 (0) 24-76928010. \\ Andri Ramadhan and Satrio Adi Wicaksono were equally contributed in this study. \\ Correspondence to $=$ Satrio Adi Wicaksono, MD. Department of Anesthesiology and Intensive Therapy. Faculty of Medicine. Diponegoro \\ University. Jl. Prof. H. Soedarto, SH., Tembalang, Semarang, Indonesia 50275. Telephone/Fax . +62 (0) 24-76928010. Email = \\ drsaw11@yahoo.com.
}

\begin{abstract}
Background: Total cholesterol is a measure of the total amount of cholesterol components including LDL (lowdensity lipoprotein), HDL (high-density lipoprotein), and VLDL (very low-density lipoprotein). Alkaline ionized water (AIW) is an electrolyzed water with a hydrogen-rich molecule and an alkaline $\mathrm{pH}$. It has a negative oxidation-reduction potential (ORP) and reactive oxygen species (ROS)-scavenging activity, which shows an antioxidant and has beneficial effects on reducing total cholesterol level, but the results still vary. This study was to investigate the effect of AIW to total cholesterol and other lipid profiles level in patients with type-2 diabetes mellitus (T2DM) accompanied by dyslipidemia.

Methods: This was a randomized double blind controlled trial performed in December 2017-December 2018. Thirty patients that had been diagnosed with T2DM accompanied by dyslipidemia in Diponegoro National Hospital Semarang and met the inclussion criteria were determined by consecutive sampling. Subjects were randomly divided into two groups: AIW group $(n=15)$ and control group (mineral water, MW) $(\mathrm{pH} 7)(\mathrm{n}=15)$. Both were administered orally 1 liter per day for 12 days; total cholesterol level and other lipid profiles were measured before and after 12 days treatment. The statistical analysis was using independent $t$-test, paired $t$-test, and nonparametric Mann-Whitney test.

Result: There were no differences between AIW group and mineral water group in all lipid profiles at before and after treatment, including total cholesterol (pre-treatment: $290.2 \pm 41.45 \mathrm{mg} / \mathrm{dL}$ vs $282.2 \pm 15.81 \mathrm{mg} / \mathrm{dL}, p=0.575$, and post-treatment: $249.8 \pm 41.17$ vs $268.5 \pm 16.73 \mathrm{mg} / \mathrm{dL}, p=0.097$ ), LDLc (pre-treatment: $167.0 \pm 9.17 \mathrm{mg} / \mathrm{dL} \mathrm{vs}$ $162.2 \pm 4.75 \mathrm{mg} / \mathrm{dL}, p=0.227$, and post-treatment: $157.2 \pm 8.88 \mathrm{mg} / \mathrm{dL}$ vs $157.6 \pm 5.39 \mathrm{mg} / \mathrm{dL}, p=0.518)$, HDLc (pre-treatment: $43.8 \pm 4.16 \mathrm{mg} / \mathrm{dL}$ vs $42.8 \pm 4.45 \mathrm{mg} / \mathrm{dL}, p=0.136$ and post-treatment: $47.1 \pm 3.24 \mathrm{mg} / \mathrm{dL}$ vs $45.2 \pm$ $1.98 \mathrm{mg} / \mathrm{dL}, p=0.142$ ), and triglyceride (pre-treatment: $351.0 \pm 119.36 \mathrm{mg} / \mathrm{dL}$ vs $381.3 \pm 59.38 \mathrm{mg} / \mathrm{dL}, p=0.934$ and post-treatment: $266.4 \pm 115.63 \mathrm{mg} / \mathrm{dL}$ vs $317.6 \pm 70.50 \mathrm{mg} / \mathrm{dL}, p=0.154)$, respectively. There was a wider differences between post- and pre-treatment of total cholesterol ( $\Delta$ total cholesterol) (40.4 $\pm 31.57 \mathrm{vs} 13.7 \pm 10.65$, $p=0.002)$, LDLc $(\Delta \mathrm{LDLc})(9.8 \pm 4.29$ vs $4.6 \pm 1.54, p=0.000)$, and HDLc $(\Delta \mathrm{HDLc})(4.3 \pm 1.87$ vs $3.4 \pm 3.11$, $p=0.031$ ) in AIW group compared to mineral water group.

Conclusion: Alkaline ionized water (AIW) decreased total cholesterol and improved other lipid profiles level in patients with T2DM accompanied by dyslipidemia. These findings might have important implications for the management of T2DM accompanied by dyslipidemia.
\end{abstract}

Keywords : alkaline ionized water, total cholesterol level, type 2 diabetes mellitus, T2DM

\section{INTRODUCTION}

The global prevalence of DM has doubled since 1980, rising from $4.7 \%$ to $8.5 \%$ in the adult population. World Health Organization (WHO) Global Report on diabetes mellitus (DM) in 2016 estimated that there was 422 million adults in the world population were living with DM in 2014, compared to 108 million in 1980.(1) International Diabetes Federation (IDF) estimated that the world numbers of patients with DM in 2015 were 415 million and were expected to increase until 642 million in 2040.(2) This increase was in line with an increase in risk factors including overweight, obese, or dyslipidemia. Diabetes prevalence has increased faster in low-to-middle-income countries than in high-income countries in the past decade, including in Indonesia. (1) Indonesian Basic Health Research (Riset Kesehatan Dasar, RISKESDAS) in 2013 revealed that the prevalence of DM in Indonesia was $1.5-2.1 \%{ }^{(3)}$
Type 2 diabetes mellitus (T2DM) is a metabolic disorder represented with chronic hyperglycemia and disorders of carbohydrate, lipid, and protein metabolism that is correlated to insulin resistence, insulin secretion defect, or their combination. Hyperglycemia has been one of fundamental diagnosis criteria of T2DM represented by increased fasting blood glucose and/or post prandial glucose. $^{(4)}$

Type 2 DM (T2DM) may initiate chronic and acute complications. It has brought 1.5 million mortalities in 2012 , and an additional 2.2 million mortalities occured in a higherthan-optimal blood glucose, by increasing the risks of cardiovascular and other diseases. ${ }^{(1)}$ Its chronic complications contained microangiopathy such as diabetic retinopathy, diabetic nephropathy, diabetic neuropathy; and macroangiopathy such as atherosclerotic cardiovascular disease (ASCVD), stroke or cerebrovascular disease (CVD), and peripheral arterial disease (PAD). ${ }^{(5)}$ Coronary 
heart disease (CHD) has caused death in more than $80 \%$ patients with T2DM. ${ }^{(5)}$

Studies indicated that the elevated extracellular and intracellular glucose levels might triger oxidative stress which played role in the pathogenesis of onset, progressivity, and complication of T2DM. ${ }^{(6-8)}$ Oxidative stress was correlated to the onset of T2DM through insulin resistance. ${ }^{(9)}$ The origin of oxidative stress derived from leakage of reactive oxygen species (ROS) from mitochondria. $(10,11)$ Some antioxidants have been examined for their properties in handling or preventing oxidative stress in T2DM. ${ }^{12}$, 13) However several studies with antioxidant supplements were failed in preventing oxidative stress-related diseases. ${ }^{(14)}$

Dyslipidemia is one of several risk factors for CHD in T2DM. It is a lipid metabolism disorder that represents as increase in total cholesterol, triglyceride (TG), low density lipoprotein cholesterol (LDLc) levels, and decrease in high density lipoprotein cholesterol (HDLc) levels. ${ }^{(15)}$ The pathogenesis of diabetic dyslipidemia is multifactorial. Insulin resistance with attendant increase in free fatty acid flux into the liver plays a central role in promoting the typical triad of diabetic dyslipidemia, namely high plasma triglyceride concentrations, low plasma HDLc, and increased concentration of small dense LDLc particles. ${ }^{(16)}$

Studies showed that the normalization of cholesterol or $\mathrm{TG}$, was essential to decrease the risk of $\mathrm{CHD}$ in patients with metabolic syndrome or T2DM. Therefore, therapy of T2DM should be followed with control of metabolic disorders such as normalization of TG and cholesterol levels, as other important therapies other than normalisation of blood glucose levels alone. ${ }^{(15)}$

Insulin resistance in T2DM influences metabolism, production, and excretion of plasma lipoprotein. Insulin resistance causes decrease of insulin effects in adipose tissue that may influence lipogenesis and lipolysis in adipose tissue, causing blood lipid increment including cholesterol and TG. These may increase LDLc level due to glucotoxicity and lipotoxicity. LDLc structure in patients with T2DM is modified, oxidized, and glycated into smaller, denser, and more atherogenic particle and a faster oxidized LDLC due to prolonged hyperglycemia. ${ }^{(15)}$ Several components have been studied to influence the level of total cholesterol, LDLc, HDLc, and TG, including AIW. ${ }^{(17,18)}$

Alkaline ionized water (AIW), an alkaline electrolysistreated water, that can increase its reduction potential, is a promising solution in providing a safe source of free electrons to block the oxidation of normal tissue by free oxygen radicals. Several studies showed that it was rich in hydogen $\left(\mathrm{H}_{2}\right)$ molecule which brought some therapeutic effects by acting as antioxidant. ${ }^{(19,20)}$ Reactive hydrogen was also considered to be the ideal scavenger of ROS in T2DM. ${ }^{(21)}$ However previous studies showed diverge interpretations in the effects of AIW to the blood glucose and lipid levels. ${ }^{(17,18,22-25)}$

Electrochemically alkaline ionized water (AIW) has been freely marketed and consumed in Indonesia, however there was still insufficient study to prove its clinical effects in patients with T2DM accompanied with dyslipidemia in Indonesia. The effects of AIW in Indonesian patients with T2DM accompanied by dyslipidemia might differ from other region since they could be influenced by genetic, race, or sosioeconomic factors.

\section{METHODS}

Study Design and Population: This study was a randomized double blind controlled trial conducted to investigate the effects of alkaline ionized water (AIW) administration on total cholesterol and other lipid profiles levels in patients with T2DM accompanied by dyslipidemia. This study involved 30 patients diagnosed with T2DM accompanied by dyslipidemia. Subjects were determined by consecutive sampling that met the inclusion criteria, namely Indonesian men and women, aged from 20 to 80 years old, undergoing routine outpatient care at Diponegoro National Hospital, Semarang, Indonesia, between December 2017-December 2018 and had been diagnosed with T2DM accompanied by dyslipidemia. The exclusion criteria were previously known cardiovascular diseases, insulin therapy, diabetic ulcer, chronic kidney disease, anemia, cancer or hematologic malignancies, infection or sepsis, lung tuberculosis, previously known autoimmune diseases, increased AST/ALT and/or creatinine of three times above normal value and major physical or mental disabilities.

Participants were randomly divided into two groups: treatment group who received alkaline ionized water (AIW) $(n=15)$ and control group who received placebo (mineral water) with neutral $\mathrm{pH}$ of $7(n=15)$. Both AIW or placebo was administered orally ad libitum with maximum of 1 liter per day for 12 days. Placebo was made to have the same appearance with AIW. Electrochemically AIW was produced with electrolysis machine.

Ethics approval for the study protocol and analysis of the data was obtained from the Ethics Committee in Health and Medical Research (KEPK) Faculty of Medicine, Diponegoro University Semarang, Indonesia. All participants had been given explanation of the purpose, benefits, research protocols, possible side effects, questionnaire, and a written informed consent.

Clinical and Laboratory Measurements: Study data included demography and medical history, physical examination, information provided by questionnaire, anthropometric measurements and laboratory measurements. The medical and drug prescription history was assessed by the examining physicians.

Diabetes mellitus was defined as either participant had history of fasting serum glucose level $\geq 126 \mathrm{mg} / \mathrm{dl}$, or serum hemoglobin A1c ( $\mathrm{HbA} 1 \mathrm{c})$ level $\geq 6.5 \%$, or the participant ever having been diagnosed with diabetes, or the current use of blood glucose-lowering agents. Hypertension was defined as either the participant ever having been diagnosed with hypertension or as having a measured blood pressure (BP) $\geq 140 / 90 \mathrm{mmHg}$ at initial examination. Trained nurses measured participants' seated BP 3 times using automated equipment (53000-E2, Welch Allyn, NY, USA) after a 5 minutes rest. Final BP was calculated as the average of BP measurements. The body mass index (BMI) was calculated by dividing weight (kilograms) by the square of height $\left(\mathrm{m}^{2}\right)$.

Participants who have met the inclusion criteria underwent a blood sampling from an antecubital vein at baseline (before treatment) and after 12 days treatment. 
Serum creatinine were determined using the Jaffe reaction method (Advia 1650 kit, Bayer Corp, PA, USA). Levels of AST and ALT were examined with International Federation of Clinical Chemistry and Laboratory Medicine (IFCC) method without Pyridoxal Phosphate in $37^{\circ} \mathrm{C}$. The serum fasting glucose and 2 hours post prandial glucose were measured by biochemical analyzer with hexokinase assay (Roche Cobas C311, Roche, Germany). All lipid profiles were collected in the fasting state and included total cholesterol, LDL cholesterol (LDLc), HDL cholesterol (HDLC), and triglyceride levels.

Statistical Analysis: Data of patients with T2DM accompanied by dyslipidemia were collected, sorted, tabulated, coded and processed using descriptive statistical methods. Data were presented as mean \pm standard deviation for continuous variables and as proportions ( $n, \%)$ for categorical variables. Categorical variables were presented as frequency distribution tables. The chi-square test was used to determine the differences in proportions for categorical variables. The continuous independent variables were compared using independent $t$-test, if normally distributed, or non-parametric Mann-Whitney test, if not normally distributed. Statistically significance was considered as $p<0.05$. All statistical analyses were performed using statistical computing program.

\section{RESULTS}

Baseline Clinical Characteristics of the Study Population: Clinical and demographic characteristics of the study population are presented in Table 1. The 30 study subjects consisted of $15(50.0 \%)$ male and 15 $(50.0 \%)$ female, and there was no difference in gender distributions between AIW group and mineral water group with $\mathrm{pH} 7(p=0.715)$. In overal, the mean age and the mean BMl of study population were $51.5 \pm 6.53$ years old and $26.2 \pm 2.97 \mathrm{~kg} / \mathrm{m}^{2}$, respectively. There was no difference in mean age $(p=0.134)$ and mean BMl $(p=0.533)$ between AIW group and mineral water group (Table 1).

There was no difference in medication history between both groups, including sulfonylureas $(p=0.195)$, biguanides $(p=0.283)$, angiotensin converting enzyme inhibitors (ACEi) or angiotensin receptor blockers (ARBs) $(p=0.409)$, B-blockers $(p=0.269)$, calcium channel blockers (CCBs) $(p=0.705)$, and statins ( $p=0.283)$ (Table 2$)$.

Blood Glucose Profiles between Alkaline Ionized Water and Mineral Water: Glucose profile in pre- and posttreatment between both groups are presented in Table 3. At baseline (pre-treatment), there were no differences between AIW group and mineral water group in fasting blood glucose (FBG) (197.6 $\pm 51.18 \mathrm{mg} / \mathrm{dL}$ vs $183.6 \pm$ $42.66 \mathrm{mg} / \mathrm{dL}$, respectively, $p=0.221$ ) and in two hours post prandial glucose (2hPPG) $(272.6 \pm 37.36 \mathrm{mg} / \mathrm{dL}$ vs $274.2 \pm$ $26.55 \mathrm{mg} / \mathrm{dL}$, respectively, $p=0.917)$. At post-treatment, there were no differences in FBG (171.6 451.29 vs $162.8 \pm$ 17.17, $p=0.934)$ and in 2hPPG (234.6 $\pm 23.11 \mathrm{mg} / \mathrm{dL}$ vs $248.2 \pm 25.32 \mathrm{mg} / \mathrm{dL}, p=0.138)$ between the AIW group and the mineral water group (Table 3).

There were lower FBG and 2hPPG both in the AIW group and mineral water group at post-treatment in comparison with at pre-treatment. There was a wider decrease between post- and pre-treatment fasting blood glucose $(\triangle \mathrm{FBG})$ in AIW group compared to mineral water group, although it was not significant $(26.0 \pm 22.16 \mathrm{mg} / \mathrm{dL}$ vs $20.7 \pm 28.70 \mathrm{mg} / \mathrm{dL}$, respectively, $p=0.346)$. There was also a wider decrease between post- and pre-treatment 2hPPG ( $\triangle 2 \mathrm{hPPG}$ ) in AIW group compared to mineral water group, although it was not significant $(41.0 \pm 31.70 \mathrm{mg} / \mathrm{dL}$ vs $26.0 \pm 25.12 \mathrm{mg} / \mathrm{dL}, p=0.212$ ) (Table 3 ).

Lipid Profiles between Alkaline Ionized Water and Mineral Water: There were no differences between AIW group and mineral water group in all lipid profiles at before and after treatment, including total cholesterol (pretreatment: $290.2 \pm 41.45 \mathrm{mg} / \mathrm{dL}$ vs $282.2 \pm 15.81 \mathrm{mg} / \mathrm{dL}$, $p=0.575$, and post-treatment: $249.8 \pm 41.17$ vs $268.5 \pm$ $16.73 \mathrm{mg} / \mathrm{dL}, p=0.097$ ), LDLc (pre-treatment: $167.0 \pm 9.17$ $\mathrm{mg} / \mathrm{dL}$ vs $162.2 \pm 4.75 \mathrm{mg} / \mathrm{dL}, p=0.227$, and post-treatment: $157.2 \pm 8.88 \mathrm{mg} / \mathrm{dL}$ vs $157.6 \pm 5.39 \mathrm{mg} / \mathrm{dL}, p=0.518)$, HDLc (pre-treatment: $43.8 \pm 4.16 \mathrm{mg} / \mathrm{dL}$ vs $42.8 \pm 4.45 \mathrm{mg} / \mathrm{dL}$, $p=0.136$ and post-treatment: $47.1 \pm 3.24 \mathrm{mg} / \mathrm{dL}$ vs $45.2 \pm$ $1.98 \mathrm{mg} / \mathrm{dL}, \quad p=0.142$ ), and triglyceride (pre-treatment: $351.0 \pm 119.36 \mathrm{mg} / \mathrm{dL}$ vs $381.3 \pm 59.38 \mathrm{mg} / \mathrm{dL}, p=0.934$ and post-treatment: $266.4 \pm 115.63 \mathrm{mg} / \mathrm{dL}$ vs $317.6 \pm 70.50$ $\mathrm{mg} / \mathrm{dL}, p=0.154$ ), respectively (table 4 ).

There were lower total cholesterol, LDLc, triglyceride, and higher HDLc both in the AIW group and mineral water group at post-treatment in comparison with at pretreatment. There was a wider differences between postand pre-treatment of total cholesterol ( $\Delta$ total cholesterol) $(40.4 \pm 31.57$ vs $13.7 \pm 10.65, p=0.002)$, LDLc $(\Delta \mathrm{LDLc})(9.8$ \pm 4.29 vs $4.6 \pm 1.54, p=0.000)$, and HDLc $(\Delta \mathrm{HDLc})(4.3 \pm$ 1.87 vs $3.4 \pm 3.11, p=0.031)$ in AIW group compared to mineral water group (Table 4).

\section{DISCUSSION}

Hyperglycemia in T2DM is thought to be correlated to oxidative stress and diabetic complications that may decrease quality of life and increase the financial burden. ${ }^{(5,}$ 26) The formation of a group of modified proteins and/or lipids with damaging potential known as advanced glycation end products (AGEs), is playing role in the development and progression of T2DM and their role in diabetic complications. ${ }^{(9)}$ Endogenous and exogenous AGEs increase ROS or free radicals formation and weaken antioxidant systems. Reactive oxygen species may cause severe oxidative damage to biological macromolecules. ${ }^{(9)}$

Studies on electrochemically AIW that have been performed in Japan showed that AIW was assumed to play role in alleviating oxidative stress-related diseases such as diabetes and dyslipidemia. Ionized water was described to be able to scavenge ROS in cultured cells. It has been presumed that the active agents in ionized water were hydrogen (atoms and molecules), mineral nanoparticles, and mineral nanoparticle hydrides. ${ }^{(19)}$

Our study showed that there was comparable fasting blood glucose (FBG) and 2hPPG in the post-treatment between AIW group and mineral water group. However, we found wider decrease of fasting blood glucose $(\triangle \mathrm{FBG})$ and $\triangle 2 \mathrm{hPPG}$ in AIW group in comparison with control group, although they were not significant. Meanwhile, this study showed that there were significant $\Delta$ total cholesterol, $\Delta \mathrm{LDLC}$, and $\Delta \mathrm{HDLc}$. These findings were difference to our previous study that showed a significant wider $\triangle \mathrm{FBG}$ in AIW group compared to control group. ${ }^{(27)}$ This might be due to different population profile between both studies, in 
which at present study, the study population were patients with T2DM accompanied with dyslipidemia, meanwhile in previous study, the study population were patients with T2DM. ${ }^{(27)}$ Unfortunately, our previous study did not calculate $\Delta$ in all lipid profiles. ${ }^{(27)}$ The existence of dyslipidemia in this present study might contribute to higher oxidative stress.

It was considered that AIW could improve total cholesterol levels within blood in which it might affect lipid metabolism process, its absorption process, and its excretion process. ${ }^{(25)}$ In the digestive process, bile salt is important for lipid solubilization and absorption, in which, the contraction of gall bladder is stimulated by cholecystokinin (CCK) hormone. ${ }^{(28,29)}$ Lipid absorption can be affected by alteration of bile salt synthesis, secretion of CCK, or bile release into the duodenum. Another important function of CCK is the inhibition of gastric emptying, that can decrease the gastric digestion result into the duodenum, so that stimulation of CCK secretion may decrease. That mechanism is a feeback system in which CCK regulate its own secretion. ${ }^{(28)}$

Kindel et al observed that lipid absorption in intestine lumen could be mediated through micelles and liposome, however the absorption of cholesterol was only mediated with micelles. ${ }^{(29)}$ Absorption through micelle is going well in low $\mathrm{pH} .{ }^{(18)}$ Inhibition of micelle solubilisation has been used as theurapetical approach to reduce hypercholesterolemia in human.(30) This hypothesis was supported with a study in a post-menopause woman which showed that there was a lower cholesterol chylomicron with a supplementation of bicarbonated mineral water. ${ }^{(18)}$ This might have similar mechanism with a supplementation of alkaline ionized water (AIW).

Laura et al showed the mechanism of how sodium bicarbonated mineral water could have its main alkaline nature by reducing lipid absorption. This was in line to our present study in which total cholesterols were significantly improved after the administration of AIW. Gastric lipase was activated in acid condition in gastric and would remain active such in $\mathrm{pH} 2$ until pankreatic bicarbonic was secreted.(31) The consumption of bicarbonated mineral water might neutralized gastric acid in stomach, and might affect hidrolysis caused by inhibition in lipase activity. Optimal function of gastric lipase is an important factor in lipolysis. Products resulting from gastric lipase (such as monoglyceride, diglyceride, and lipid acid) could stimulate the secretion of CCK and the activation of pankreatic lipase colipase in supporting the activity of pankreatic lipase. ${ }^{(28,32)}$ The action of pankreas lipase in intestinal lumen would be disturbed if there was inhibition in activation of pankreatic lipase colipase. ${ }^{(33)}$ Triglyceride that was not hydrolysed by pankreatic lipase could not induce the secretion of CCK. The reduction of CCK levels due to the inhibition of lipase activity might cause the reduction in gall bladder contraction, so that reduced the secretion of bile salts to the duodenum, in which further might reduce lipid absorption. (34) It was hypothezised that the alteration of gastrointestinal tract acidity might alter lipid absorption.

Most peripheral cells are unable to metabolize cholesterol. Thus the transport of excess cholesterol from peripheral tissue to return to the liver, which is known as reverse cholesterol transport, is the only mechanism to keep the homeostasis of cholesterol in vivo. The pathway of reverse cholesterol transport can be divided into three main steps: 1) uptake cellular cholesterol by HDL; 2) esterification of HDL by lecitin: acyltransferase cholesterol; and 3) captation of HDL cholesteryl esters by liver in which cholesterol can be metabolized and excreted through bile. ${ }^{(18)}$

The consumption of bicarbonated mineral water or AIW was thought to cause the increase of reverse cholesterol transport due to the increment of HDLc level. It was thought that only HDLc that had the ability to eliminate unesterified cholesterol in bile through reverse cholesterol transport mechanism. Schoppen et al showed that bicarbonated mineral water that had an alkaline nature could improve serum triacylglycerol consentration compared than water with low mineral content. Serum triglyceride consentration showed lower value with administration of bicarbonated water that might correlate with faster hydrolysis from triacylglycerol into the circulation. $^{(18)}$

Several studies showed that hydrogen $\left(\mathrm{H}_{2}\right)$ molecule in alkaline reduced water could bring therapetic benefits as an antioxidant. One of the merits was to reduce glucose levels or as anti-diabetes. ${ }^{(19,20,22,23,35,36)}$ Hita Tenryosui water, an electrolysed reduced water, and Nordenau water, a natural reduced water, have been shown to scavange intracellular ROS in a hamster pancreatic $\beta$ cell line HITT15 cells, and improve the secretion of insulin. $(22,24)$ Reduced water, Hita Tenryosui water and Nordenau water, also scavanged ROS in rat L6 myotube cells and improved sugar uptake. $(22,24,37)$ These waters also could alleviate sugar tolerance damage in T2DM model mice, $(22,24,38)$ meanwhile electrolysed reduced water derived from tap water has been reported to improve the symptoms of diabetes model mice. (21) Other report also showed that alloxan-induced oxidative damage was suppressed by electrolysed reduced water and natural reduced water in cells and in alloxan-induced type 1 diabetes model mice. ${ }^{(23)}$

Pancreatic beta cells are secreting insulin that is consist of amino acids series and has role in glucose uptake into the cells. Glucose transporters (GLUTs) are amino acids that are responsible in transporting glucose in insulin in which the majority of them that is responsible in it is GLUT-4. Hita Tenryosui water and Nordenau water might induce the phosphorylation of the insulin receptors by suppressing of the activity of tyrosine protein phosphatase, a redox-sensitive protein, and might activate phophatidylinositol-3-kinase (PI-3-kinase) and Akt, as well as might induce the translocation of the sugar transport carrier GLUT4 to the cell membrane to promote intracellular glucose uptake. (19, 24, 36) $^{-1}$

The formation of ROS was thought to cause extensive oxidative damage to biomolecules such as DNA, RNA, and protein. Lee $M$ et al studied the preventive, suppressive, and protective effects of in vitro supplementation with electrolyzed-ionized water on $\mathrm{H}_{2} \mathrm{O}_{2}$-induced DNA damage in human lymphocytes. Lee $\mathrm{M}$ et al revealed that pretreatment, co-treatment, and post-treatment with electrolyzed-ionized water improved human lymphocyte resistance to the DNA strand breaks induced by $\mathrm{H}_{2} \mathrm{O}_{2}$ in vitro. lonized water inhibited single-strand breakage of DNA caused by ROS produced by the $\mathrm{Cu}$ (II)-catalyzed oxidation 
of ascorbic acid in a dose-dependent manner. ${ }^{(39)}$ It seemed that ionized water could scavenge not only $\mathrm{O}_{2} \cdot{ }^{-}$and $\mathrm{H}_{2} \mathrm{O}_{2}$, but also $\mathrm{O}_{2}$ and $\mathrm{OH}^{-}$. lonized water reduced the amount of $\mathrm{H}_{2} \mathrm{O}_{2}$ produced by XOD in an SOD accumulated $\mathrm{H}_{2} \mathrm{O}_{2}$ in the HX-XOD system. ${ }^{(36)}$

Several limitations should be considered. First, we only studied patients with T2DM accompanied by dyslipidemia who were stable non-complicated condition, we were not able to generalize this results to patients in more severe clinical condition. Second, the real mechanism of how ionized water could improve lipid profile could not be fully explained yet from our study. Third, we could not explain why $\Delta$ triglyceride was not improved in this study. Fourth, we could not avoid the influence of patients' complience to anti-diabetic, anti-cholesterol, or other drugs, diet, and physical activities.

Table 1. Baseline Characteristics of Study Population

\begin{tabular}{|c|c|c|c|c|}
\hline \multirow[t]{2}{*}{ Parameter } & \multicolumn{2}{|l|}{ Group } & \multirow[t]{2}{*}{ Total $(n=30)$} & \multirow[t]{2}{*}{$P$} \\
\hline & Alkaline lonized Water $(\mathrm{n}=15)$ & Mineral Water $(n=15)$ & & \\
\hline $\begin{array}{l}\text { Gender }(n, \%) \\
\text { Male } \\
\text { Female }\end{array}$ & $\begin{array}{l}7(23.3 \%) \\
8(26.7 \%)\end{array}$ & $\begin{array}{l}8(26.7 \%) \\
7(23.3 \%)\end{array}$ & $\begin{array}{l}15(50.0 \%) \\
15(50.0 \%)\end{array}$ & $0.715 \phi$ \\
\hline Age (years) & $52.7 \pm 6.1 ; 53.0(36.0-60.0)$ & $50.3 \pm 6.92 ; 48.0(43.0-65.0)$ & $51.5 \pm 6.5352 .0(36.0-65.0)$ & 0.134 ף \\
\hline Body Weight (kg) & $72.2 \pm 10.50 ; 70.0(60.0-100.0)$ & $73.6 \pm 3.60 ; 75.0(68.0-78.0)$ & $\begin{array}{l}72.9 \pm 7.74 ; 72.0(60.0- \\
100.0)\end{array}$ & 0.087 ף \\
\hline Height (cm) & $\begin{array}{l}169.4 \pm 2.82 ; 169.0(165.0- \\
176.0)\end{array}$ & $\begin{array}{l}172.2 \pm 4.21 ; 175.0(164.0- \\
176.0)\end{array}$ & $\begin{array}{l}170.8 \pm 3.80 ; 170.0(164.0- \\
176.0)\end{array}$ & 0.057 ף \\
\hline Body Mass Index (BMI) $\left(\mathrm{kg} / \mathrm{m}^{2}\right)$ & $26.6 \pm 4.04 ; 25.9(19.3-35.4)$ & $25.7 \pm 1.21 ; 25.7(24.2-29.4)$ & $\begin{array}{l}26.2 \pm 2.97 ; 25.7(19.3- \\
35.4)\end{array}$ & 0.533 ף \\
\hline Hypertension (n, \%) & $15(50.0 \%)$ & $15(50.0 \%)$ & $30(100.0 \%)$ & \\
\hline Smoking (n, \%) & & & & $0.701 \phi$ \\
\hline Current smoker & $4(13.3 \%)$ & $3(10.0 \%)$ & $7(23.3 \%)$ & \\
\hline Ex-smoker & $3(10.0 \%)$ & $5(16.7 \%)$ & $8(26.7 \%)$ & \\
\hline Non smoker & $8(26.7 \%)$ & $7(23.3 \%)$ & $15(50.0 \%)$ & \\
\hline Exercise (n \%) & & & & \\
\hline$\leq 2$ times/week & $13(43.3 \%)$ & $8(26.7 \%)$ & $21(70.0 \%)$ & $0.046^{*} \phi$ \\
\hline$>2$ times/week & $2(6.7 \%)$ & $7(23.3 \%)$ & $9(30.0 \%)$ & \\
\hline Systolic Blood Pressure $(\mathrm{mmHg})$ & $\begin{array}{l}143.8 \pm 5.36 ; 145.0(132.0- \\
152.0)\end{array}$ & $\begin{array}{l}146.0 \pm 5.86 ; 147.0(136.0- \\
154.0)\end{array}$ & $\begin{array}{l}144.9 \pm 5.63 ; 145.5(132.0- \\
154.0)\end{array}$ & $0.278 \S$ \\
\hline Diastolic Blood Pressure $(\mathrm{mmHg})$ & $88.8 \pm 4.81 ; 89.0(81.0-95.0)$ & $86.8 \pm 3.44 ; 86.0(82.0-94.0)$ & $\begin{array}{l}87.8 \pm 4.22 ; 88.0(81.0- \\
95.0)\end{array}$ & $0.216 \S$ \\
\hline Mean Arterial Pressure $(\mathrm{mmHg})$ & $\begin{array}{l}106.8 \pm 3.54 ; 106.0(101.0- \\
113.0)\end{array}$ & $\begin{array}{l}106.4 \pm 2.82 ; 106.0(101.0- \\
112.0)\end{array}$ & $\begin{array}{l}106.6 \pm 3.15 ; 106.0(101.0- \\
113.0)\end{array}$ & $0.735 \S$ \\
\hline Hemoglobin (g/dL) & $12.8 \pm 0.66 ; 13.0(11.5-14.1)$ & $12.8 \pm 0.51 ; 12.7(12.1-13.8)$ & $\begin{array}{l}12.8 \pm 0.58 ; 12.8(11.5- \\
14.1)\end{array}$ & 0.867 ף \\
\hline Leukocyte $\left(10^{3} / \mu \mathrm{L}\right)$ & $7.4 \pm 1.06 ; 7.5(6.2-9.4)$ & $7.4 \pm 1.06 ; 7.3(6.2-9.4)$ & $7.4 \pm 1.04 ; 7.4(6.2-9.4)$ & $0.973 \S$ \\
\hline Platelet $\left(10^{3} / \mu \mathrm{L}\right)$ & $\begin{array}{l}493.9 \pm 59.33 ; 480.0(410.0- \\
650.0)\end{array}$ & $\begin{array}{l}450.3 \pm 65.66 ; 465.0(300.0- \\
550.0)\end{array}$ & $\begin{array}{l}472.1 \pm 65.36 ; 475.0(300.0 \\
-650.0)\end{array}$ & 0.124 ף \\
\hline $\operatorname{Ureum}(\mathrm{mg} / \mathrm{dL})$ & $42.2 \pm 6.75 ; 44.0(30.0-55.0)$ & $44.8 \pm 5.38 ; 46.0(35.0-55.0)$ & $\begin{array}{l}43.5 \pm 6.14 ; 45.0(30.0- \\
55.0)\end{array}$ & 0.166 ף \\
\hline Creatinine $(\mathrm{mg} / \mathrm{dL})$ & $0.6 \pm 0.15 ; 0.6(0.4-0.9)$ & $0.6 \pm 0.14 ; 0.6(0.4-0.9)$ & $0.6 \pm 0.15 ; 0.6(0.4-0.9)$ & $0.934 \S$ \\
\hline
\end{tabular}

*significant if $p<0.05$. Presented as mean \pm SD; median (min - max).

$\phi$ Chi-square test; § Independent $t$-test; I Non-parametric Mann-Whitney test.

Table 2. Medication History of Study Population

\begin{tabular}{|l|l|l|l|l|}
\hline Characteristics & Alkaline lonized Water $(\mathrm{n}=15)$ & Mineral Water $(\mathrm{n}=15)$ & $\begin{array}{l}\text { Total } \\
\mathrm{n}(\%)\end{array}$ & $P$ \\
\hline & & & & \\
\hline Sulfonylureas & & & $23(76.7 \%)$ & \\
\hline Yes & $10(33.3 \%)$ & $13(43.3 \%)$ & $7(23.3 \%)$ & 0.195 \\
\hline No & $5(16.7 \%)$ & $2(6.7 \%)$ & & \\
\hline Biguanides & & & & \\
\hline Yes & & $14(46.7 \%)$ & $26(86.7 \%)$ & 0.283 \\
\hline
\end{tabular}


The Effects of Alkaline lonized Water Administration to the Total Cholesterol Levels in Patients with Type 2 Diabetes Mellitus

\begin{tabular}{|c|c|c|c|c|}
\hline No & $3(10.0 \%)$ & $1(3.3 \%)$ & $4(13.3 \%)$ & \\
\hline \multicolumn{5}{|c|}{ ACEi/ARBs } \\
\hline Yes & $10(33.3 \%)$ & $12(40.0 \%)$ & $22(73.3 \%)$ & 0.409 \\
\hline No & $5(16.7 \%)$ & $3(10.0 \%)$ & $8(26.7 \%)$ & \\
\hline \multicolumn{5}{|c|}{ B-Blockers } \\
\hline Yes & $5(16.7 \%)$ & $8(26.7 \%)$ & $13(43.3 \%)$ & 0.269 \\
\hline No & $10(33.3 \%)$ & $7(23.3 \%)$ & $17(56.7 \%)$ & \\
\hline \multicolumn{5}{|c|}{ CCBs } \\
\hline Yes & 10 (33.3\%) & $9(30.0 \%)$ & $19(63.3 \%)$ & 0.705 \\
\hline No & $5(16.7 \%)$ & $6(20.0 \%)$ & $11(36.7 \%)$ & \\
\hline \multicolumn{5}{|c|}{ Statins } \\
\hline Yes & $14(46.7 \%)$ & $12(40.0 \%)$ & $26(86.7 \%)$ & 0.283 \\
\hline No & $1(3.3 \%)$ & $3(10.0 \%)$ & $4(13.3 \%)$ & \\
\hline
\end{tabular}

* significant if $p<0.05$ between alkaline ionized water and mineral water with Chi-square test.

$\mathrm{ACEi}$, angiotensin converting enzyme inhibitors; ARBs, angiotensin receptor blockers; CCBs, calcium channel blockers.

Table 3. Blood Glucose Profile between Alkaline lonized Water Group and Control Group

\begin{tabular}{|c|c|c|c|}
\hline \multirow[t]{2}{*}{ Parameter } & \multicolumn{2}{|l|}{ Group } & \multirow[t]{2}{*}{$P$} \\
\hline & Alkaline lonized Water $(n=15)$ & Mineral Water $(n=15)$ & \\
\hline FBG Pre-treatment (mg/dL) & $197.6 \pm 51.18 ; 180.0(116.0-289.0)$ & $183.6 \pm 42.66 ; 162.0(142.0-264.0)$ & $0.221 \pi$ \\
\hline FBG Post-treatment (mg/dL) & $171.6 \pm 51.29 ; 176.0(103.0-264.0)$ & $162.8 \pm 17.17 ; 159.0(140.0-202.0)$ & $0.934 \mathrm{I}$ \\
\hline$\Delta \mathrm{FBG}$ & $26.0 \pm 22.16 ; 19.0(1.0-71.0)$ & $20.7 \pm 28.70 ; 4.0(2.0-81.0)$ & 0.346 ף \\
\hline 2h PPG, Pre-treatment (mg/dL) & $272.6 \pm 37.36 ; 278.0(215.0-320.0)$ & $274.2 \pm 26.55 ; 262.0(242.0-324.0)$ & $0.917 \mathrm{I}$ \\
\hline 2h PPG, Post-treatment (mg/dL) & $234.6 \pm 23.11 ; 228.0(203.0-277.0)$ & $248.2 \pm 25.32 ; 255.0(210.0-295.0)$ & $0.138 \S$ \\
\hline$\triangle 2 \mathrm{~h} P P G$ & $41.0 \pm 31.70: 42.0(1.0-94.0)$ & $26.0 \pm 25.12: 12.0(2.0-71.0)$ & $0.212 \mathrm{I}$ \\
\hline
\end{tabular}

*significant if $p<0.05$. Presented as mean $\pm \mathrm{SD} ;$ median ( $\min -\mathrm{max})$.

$\S$ Independent $t$-test; ๆ Non-parametric Mann-Whitney test.

FBG, fasting blood glucose; $2 \mathrm{~h}$ PPG, two hours post-prandial glucose.

Table 4. Lipid Profile between Alkaline lonized Water Group and Control Group

\begin{tabular}{|c|c|c|c|}
\hline \multirow[t]{2}{*}{ Parameter } & \multicolumn{2}{|l|}{ Group } & \multirow[t]{2}{*}{$P$} \\
\hline & Alkaline lonized Water $(n=15)$ & Mineral Water $(n=15)$ & \\
\hline Total cholesterol Pre-treatment $(\mathrm{mg} / \mathrm{dL})$ & $290.2 \pm 41.45 ; 292.0(204.0-360.0)$ & $282.2 \pm 15.81 ; 276.0(263.0-321.0)$ & 0.575 ๆ \\
\hline Total cholesterol Post-treatment (mg/dL) & $249.8 \pm 41.17 ; 252.0(129.0-312.0)$ & $268.5 \pm 16.73 ; 267.0(241.0-310.0)$ & 0.097 I \\
\hline$\Delta$ total cholesterol $(\mathrm{mg} / \mathrm{dL})$ & $40.4 \pm 31.57 ; 24.0(8.0-116.0)$ & $13.7 \pm 10.65 ; 11.0(2.0-40.0)$ & $0.002^{*} \mathbb{I}$ \\
\hline LDLc Pre-treatment (mg/dL) & $167.0 \pm 9.17 ; 164.0(157.0-187.0)$ & $162.2 \pm 4.75 ; 163.0(154.0-169.0)$ & 0.227 I \\
\hline LDLc Post-treatment (mg/dL) & $157.2 \pm 8.88 ; 156.0(145.0-177.0)$ & $157.6 \pm 5.39 ; 158.0(149.0-166.0)$ & 0.518 ๆ \\
\hline$\Delta \mathrm{LDLC}(\mathrm{mg} / \mathrm{dL})$ & $9.8 \pm 4.29 ; 10.0(4.0-17.0)$ & $4.6 \pm 1.54 ; 5.0(2.0-8.0)$ & $0.000 * \S$ \\
\hline HDLc Pre-treatment (mg/dL) & $43.8 \pm 4.16 ; 44.0(38.0-51.0)$ & $42.8 \pm 4.45 ; 42.0(34.0-48.0)$ & $0.136 \S$ \\
\hline HDLc Post-treatment (mg/dL) & $47.1 \pm 3.24 ; 48.0(43.0-52.0)$ & $45.2 \pm 1.98 ; 45.0(42.0-49.0)$ & 0.142 爪 \\
\hline$\triangle \mathrm{HDLC}$ & $4.3 \pm 1.87 ; 4.0(1.0-6.0)$ & $3.4 \pm 3.11 ; 3.0(1.0-10.0)$ & $0.031^{*} \S$ \\
\hline Triglyceride Pre-treatment $(\mathrm{mg} / \mathrm{dL})$ & $351.0 \pm 119.36 ; 415.0(130.0-485.0)$ & $381.3 \pm 59.38 ; 395.0(280.0-465.0)$ & 0.934 व \\
\hline Triglyceride Post-treatment (mg/dL) & $266.4 \pm 115.63 ; 270.0(110.0-412.0)$ & $317.6 \pm 70.50 ; 315.0(180.0-419.0)$ & $0.154 \S$ \\
\hline$\Delta$ triglyceride $(\mathrm{mg} / \mathrm{dL})$ & $84.6 \pm 80.30 ; 50.0(16.0-112.0)$ & $63.7 \pm 61.14 ; 45.0(5.0-100.0)$ & 0.430 ๆ \\
\hline
\end{tabular}

*significant if $p<0.05$. Presented as mean \pm SD; median (min - max).

$\S$ Independent $t$-test; $\uparrow$ Non-parametric Mann-Whitney test.

LDLc, low density lipoprotein cholesterol; HDLc, high density lipoprotein cholesterol.

\section{REFERENCES}

1. Global Report on Diabetes. Geneva: World Health Organization; 2016.
2. International Diabetes Federation Diabetes Atlas. 7 ed. Karakas: International Diabetes Federation; 2015.

3. Riset Kesehatan Dasar (RISKESDAS) 2013. Jakarta: Badan Penelitian dan Pengembangan Kesehatan Kementerian Kesehatan RI; 2013. 
4. Grant RW, Donner TW, Fradkin JE, Hayes C, Herman WH, Hsu WC, et al. Classification and diagnosis of diabetes: standards of medical care in diabetes 2015. Diabetes Care. 2015;38(Suppl. 1):S8-S16.

5. Chiang JL, Berg EG, McElvaine AT. American Diabetes Association: Standards of Medical Care in Diabetes 2016. Diabetes Care. 2016;39(Supplement 1):S1-S112.

6. Paneni F, Beckman JA, Creager MA, Cosentino F. Diabetes and vascular disease: pathophysiology, clinical consequences, and medical therapy: part I. Eur Heart J. 2013;34(31):2436-43.

7. Singhania N, Puri D, Madhu SV, Sharma SB. Assessment of oxidative stress and endothelial dysfunction in Asian Indians with type 2 diabetes mellitus with and without macroangiopathy. Q J Med. 2008;101(6):449-55.

8. Rosen P, Nawroth PP, King G, Moller W, Tritschler HJ, Packer $\mathrm{L}$. The Role of Oxidative Stress in the onset and progression of diabetes and Its complications: a summary of a Congress Series sponsored by UNESCO-MCBN, the American Diabetes Association and the German Diabetes Society. Diabetes Metab Res Rev. 2001;17(3):189-212.

9. Nowotny K, Jung T, Hohn A, Weber D, Grune T. Advanced glycation end products and oxidative stress in type 2 diabetes mellitus. Biomolecules. 2015;5(1):194-222.

10. Niedowicz DM, Daleke DL. The Role of Oxidative Stress in Diabetic Complications. Cell Biochem Biophys. 2005;43(2):289-330.

11. West IC. Radicals and oxidative stress in diabetes. Diabet Med. 2000;17(3):171-80.

12. Bajaj S, Khan A. Antioxidants and diabetes. Indian journal of endocrinology and metabolism. 2012;16(Suppl 2):S267-71.

13. Bloomgarden ZT. Antioxidants and Diabetes. Diabetes Care. 1997;20(4):670-3.

14. Steinhubl SR. Why Have Antioxidants Failed in Clinical Trials? Am J Cardiol. 2008;101(Supplement 10):14D-9D.

15. Chehade JM, Gladysz M, Mooradian AD. Dyslipidemia in type 2 diabetes: prevalence, pathophysiology, and management. Drugs. 2013;73(4):327-39.

16. Mooradian AD. Dyslipidemia in type 2 diabetes mellitus. Nat Clin Pract Endocrinol Metab. 2009;5:150-9.

17. Kajiyama S, Hasegawa G, Asano M, Hosoda H, Fukui M, Nakamura N, et al. Supplementation of hydrogen-rich water improves lipid and glucose metabolism in patients with type 2 diabetes or impaired glucose tolerance. Nutrition research. 2008;28(3):137-43.

18. Schoppen S, Perez-Granados AM, Carbajal A, Sarria B, Sanchez-Muniz FJ, Gomez-Gerique JA, et al. Sodium bicarbonated mineral water decreases postprandial lipaemia in postmenopausal women compared to a low mineral water. The British journal of nutrition. 2005;94(4):582-7.

19. Shirahata S, Hamasaki T, Teruya K. Advanced research on the health benefit of reduced water. Trends Food Sci Technol. 2012;23(2):124-31.

20. Ohta S, Nakao A, Ohno K. The 2011 Medical Molecular Hydrogen Symposium: An inaugural symposium of the journal Medical Gas Research. Med Gas Res. 2011;1(1):10.

21. Kim M-J, Kim HK. Anti-diabetic effects of electrolyzed reduced water in streptozotocin-induced and genetic diabetic mice. Life sciences. 2006;79(24):2288-92.

22. Osada K, Li Y, Hamasaki T, Abe M, Nakamichi N, Teruya K, et al. Anti-Diabetes Effects of Hita Tenryou-Sui Water®, a Natural Reduced Water. In: Kamihira M, Katakura Y, Ito A, editors. Animal Cell Technology: Basic \& Applied Aspects. 16. Dordrecht: Springer, Dordrecht; 2010. p. 307-13.

23. Li Y, Hamasaki T, Teruya K, Nakamichi N, Gadek Z, Kashiwagi $T$, et al. Suppressive effects of natural reduced waters on alloxan-induced apoptosis and type 1 diabetes mellitus. Cytotechnology. 2012;64(3):281-97.

24. Gadek Z, Hamasaki T, Shirahata S. "Nordenau Phenomenon" - Application of Natural Reduced Water to Therapy: Follow-Up Study upon 411 Diabetes Patients. In: Shirahata S, Ikura K, Nagao M, Ichikawa A, Teruya K, editors. Animal Cell Technology: Basic \& Applied Aspects. 15. Dordrecht: Springer, Dordrecht; 2008. p. 265-71.

25. Sato Y, Kajiyama S, Amano A, Kondo Y, Sasaki T, Handa S, et al. Hydrogen-rich pure water prevents superoxide formation in brain slices of vitamin C-depleted SMP30/GNL knockout mice. Biochem Biophys Res Commun. 2008;375(3):346-50.

26. American Diabetes A. Economic costs of diabetes in the U.S. In 2007. Diabetes Care. 2008;31(3):596-615.

27. Wicaksono SA, Nabyla DH, Utami SB. The Effects of Alkaline Reduced Water Administration to the Fasting Blood Glucose Levels in Patients with Type 2 Diabetes Mellitus. Pak J Med Health Sci. 2020 14(3):1260-5.

28. Otsuki M. Interaction among fat, lipase, CCK, and gastric emptying. J Gastroenterol. 1999;34(4):542-4.

29. Kindel T, Lee DM, Tso P. The mechanism of the formation and secretion of chylomicrons. Atheroscler Suppl. 2010;11(1):11-6.

30. Lima J, Fonollosa V, Chacón P. Selective cholesterol absorption inhibition as a new prospect in treatment of hypercholesterolemia. Med Clin (Barc). 2005;125(1):16-23.

31. Aloulou A, Carrière F. Gastric lipase: an extremophilic interfacial enzyme with medical applications. Cell Mol Life Sci. 2008;65(6):851-4.

32. Embleton JK, Pouton CW. Structure and function of gastrointestinal lipases. Advanced Drug Delivery Reviews. 1997;25(1):15-32.

33. Watanabe S, Lee KY, Chang TM, Berger-Ornstein L, Chey WY. Role of pancreatic enzymes on release of cholecystokinin-pancreozymin in response to fat. Am J Physiol. 1988;254(6 Pt 1):G837-G42.

34. Hildebrand $P$, Petrig $C$, Burckhardt B, Ketterer S, Lengsfeld $\mathrm{H}$, Fleury $\mathrm{A}$, et al. Hydrolysis of dietary fat by pancreatic lipase stimulates cholecystokinin release. Gastroenterology. 1998;114(1):123-9.

35. Hayashi $\mathrm{H}$, Kawamura $\mathrm{M}$. Clinical Applications of Electrolyzed-Reduced Water. In: Shirahata S, Teruya K, Katakura Y, editors. Animal Cell Technology: Basic \& Applied Aspects. 12. Dordrecht: Springer, Dordrecht; 2002. p. 31-6.

36. Shirahata S, Kabayama S, Nakanoa M, Miura T, Kusumoto $\mathrm{K}$, Gotoh $\mathrm{M}$, et al. Electrolyzed-reduced water scavenges active oxygen species and protects DNA from oxidative damage. Biochem Biophys Res Commun. 1997;234(1):26974.

37. Park S-K, Park S-K. Electrolyzed-reduced water increases resistance to oxidative stress, fertility, and lifespan via insulin/IGF-1-like signal in C. elegans. Biol Res. 2013;46(2):147-52.

38. Gadek Z, Shirahata S. Changes in the Relevant Test Parameters of 101 Diabetes Patients under the Influence of the So-Called "Nordenau-Phenomenon". In: Shirahata S, Teruya K, Katakura Y, editors. Animal Cell Technology: Basic \& Applied Aspects. 12. Dordrecht: Springer, Dordrecht; 2002.

39. Lee MY, Kim YK, Ryoo KK, Lee YB, Park EJ. Electrolyzedreduced water protects against oxidative damage to DNA, RNA, and protein. Appl Biochem Biotechnol. 2006;135(2):133-44 